\title{
Karolina Łopacińska
}

Uniwersytet Ekonomiczny we Wrocławiu

Wydział Nauk Ekonomicznych

e-mail: lopacinska.karolina@gmail.com

\section{One Belt One Road jako wyraz globalnej ekspansji Chin}

Kody JEL: F53, J51

Słowa kluczowe: One Belt One Road, OBOR, Nowy Jedwabny Szlak, Chiny, globalna ekspansja, współpraca

Streszczenie: Inicjatywa władz ChRL One Belt One Road, skoncentrowana na rozbudowie sieci infrastruktury łączącej Chiny, kraje Azji Środkowej, Bliskiego Wschodu, Afryki i Europy ma rozszerzyć wzajemną współpracę tych krajów w realizacji projektów o charakterze infrastrukturalnym oraz finansowym. Inicjatywa będzie miała więc kluczowe znaczenie dla rozwoju gospodarki chińskiej, współpracujących z nią krajów i regionów świata. $\mathrm{W}$ artykule przedstawiono istotę, znaczenie oraz przewidywany wpływ tego strategicznego projektu ekonomicznego zarówno na rynek europejski, jak i światowy.

\section{Wprowadzenie}

Program reform społeczno-gospodarczych zainicjowanych w 1978 roku przez Xiaopinga zapoczątkował okres rozwoju chińskiej gospodarki i ekspansji firm chińskich oraz wpłynął na stopniową zmianę gospodarczego i społecznego wizerunku kraju. Chińska Republika Ludowa dzięki temu odbudowuje swoje relacje gospodarcze i polityczne $\mathrm{z}$ wieloma państwami, jednocześnie wypracowując podstawy postępu ekonomicznego (Guthrie, 2009). W szczególności trzeba podkreślić wdrożenie strategii Go Global, co spowodowało ogromny postęp chińskiej gospodarki. Obecnie chińscy inwestorzy prowadzą działalność w po- 
nad 132 krajach i regionach na całym świecie. Jak wynika z raportów Organizacji Narodów Zjednoczonych, wartość chińskich inwestycji zagranicznych wzrosła z 2,7 mld USD w roku 2002 aż do 84,2 mld w roku 2012. Pozwoliło to Chinom na awans z szóstego w 2011 roku na trzecie miejsce najbardziej aktywnych krajów pod względem podejmowania bezpośrednich inwestycji zagranicznych w roku 2012 (Pinkerton, 2014), a w kolejnych latach pozycja ta została utrzymana, przy poziomie inwestycji 170,1 mld USD w 2016 roku.

Najwięcej inwestycji chińskich, zróżnicowanych branżowo zostało zlokalizowanych na rynkach Azji i Europy. Przedsiębiorcy chińscy są bowiem zainteresowani inwestowaniem w wiele dziedzin, a w szczególności w te traktowane jako priorytetowe w dwunastym Pięcioletnim Planie Gospodarczym. Należą do nich sektory: technologii energetycznych, biotechnologii, nowej generacji technologii informacyjnych, przemysłu towarów wysoko przetworzonych, a także sektory nowych materiałów i alternatywnych źródeł energii oraz pojazdów na biopaliwa. Obecnie w obliczu spowolnienia gospodarki, Chiny nieustannie poszukują nowych bodźców, które pobudziłyby tempo wzrostu i rozwoju.

Analizując przewidywane perspektywy rozwojowe chińskiego rynku należy podkreślić znaczenie jednej z głównych inicjatyw rządu Chin - One Belt One Road (OBOR) - mającej na celu reaktywację Jedwabnego Szlaku oraz zapewnienie lepszych połączeń transportowych i handlowych wewnątrz Państwa Środka, jak również między ChRL a państwami Europy, Azji oraz Afryki. W wyznaczonych przez One Belt One Road ramach chińscy inwestorzy będą mieli szansę łatwiejszego prowadzenia działalności gospodarczej i budowania relacji z partnerami zagranicznymi. Zdaniem ekspertów powodzenie projektu ma znaczenie fundamentalne, gdyż w przypadku wielu obszarów, a w tym również zachodniej części Chin, przyczyni się ono nie tylko do złagodzenia regulacji dotyczących przepływów kapitałowych między państwami oraz internacjonalizacji chińskiego yuana, ale przede wszystkim do znacznego postępu cywilizacyjnego (Action plan ..., 2015).

Celem artykułu jest przedstawienie istoty, znaczenia oraz przewidywanego wpływu tego strategicznego projektu ekonomicznego na rynek europejski oraz światowy.

\section{One Belt One Road - główne założenia projektu i jego znaczenie}

Projekt inicjatywy One Belt One Road został przedstawiony po raz pierwszy przez przewodniczącego ChRL Xi Jinpinga we wrześniu 2013 roku, podczas jego wizyty w Kazakhstanie. W swoim wystąpieniu na Uniwersytecie Nazarbayewa. Jinping oficjalnie przedstawił pomysł utworzenia lądowej trasy handlowo-transportowej łączącej Chiny i Europę w ramach tzw. Silk Road Economic Belt. Tego samego roku w październiku, w czasie wizyty w Indonezji przewodniczący przedstawił z kolei wizję utworzenia Maritime Silk Road, 
w ramach którego przewiduje się budowę połączeń między krajami Azji, Europy i Afryki (Mittelstaedt, 2016; Jedwabny..., 2017). Obie trasy mają się rozwijać równolegle w ramach inicjatywy One Belt One Road i oznaczają budowę nowej lub modernizację już istniejącej sieci infrastruktury transportowej oraz kolejowej.

Istotną rolę zwłaszcza dla europejskich przewoźników odgrywa linia kolei transsyberyjskiej, która umożliwia dostęp do północnych obszarów Państwa Środka, tzw. Korytarzem Północnym oraz połączeń kolejowych już wewnątrz samych Chin. Dążąc do niezależności od innych krajów oraz kontroli sytuacji, rząd Chin tworzy ponadto koncepcję Korytarza Centralnego, który umożliwiłby handlowcom całkowite ominięcie Rosji. Trasa ta biegłaby od chińskiej granicy przez Kazachstan, a następnie odbijałaby na południe w kierunku Uzbekistanu i Turkmenistanu oraz dalej ciągnęłaby się przez Iran, Turcję aż do Europy. Nowa Trasa będzie wprawdzie dłuższa od pierwotnej, umożliwi jednak całkowite uniezależnienie się od Rosji, a co więcej stworzy szansę handlu z państwami przez które ma przebiegać.

W planie rządu Chin jest również budowa nowych lub modernizacja już istniejących linii kolejowych z Chin do Singapuru, a także z Chin do Bangladeszu, Pakistanu, Indii, Iranu, oraz dalej do Turcji i krajów europejskich. Trasa biegnąca przez te kraje, umożliwiłaby ominięcie pasma górskiego Himalajów od południa, tworząc tzw. Korytarz Południowy. Stworzyłoby to możliwość dostępu do dalszych terenów kontynentu azjatyckiego oraz szanse na większą dywersyfikację towarów podlegających wymianie, dostosowanych do specyfiki nowych rynków.

Szlak morski z kolei ma planowo rozpoczynać się w południowowschodniej prowincji Guandong i biec wzdłuż wybrzeży Azji PołudniowoWschodniej, przez cieśninę Malakkę, Sri Lankę, Ocean Indyjski, a następnie przez Róg Afryki i Kanał Sueski aż do Morza Śródziemnego, gdzie handlowcy będą mieli możliwość wybrania właściwych dla siebie wariantów dalszej trasy, w kierunku Europy Północnej lub Południowej, a tam już będzie istniała możliwość skorzystania ze szlaku lądowego. Należy przy tym podkreślić znaczenie handlu morskiego, który odznacza się wyższym poziomem rozwoju w porównaniu z handlem lądowym. Wielkość realizowanych drogą morską obrotów handlowych wykazuje dominujący udział w światowych obrotach handlowych. Mimo osiągnięcia już wysokiego poziomu rozwoju transportu morskiego, rząd Chin wciąż widzi w nim potencjał dalszego rozwoju. Druga część Morskiego Jedwabnego Szlaku ma dlatego przebiegać właśnie w kierunku południowego Pacyfiku, postrzeganego jako obszar naturalnego rozwoju dla chińskiego handlu morskiego.

Analizując trasy zarówno lądowego, jak i morskiego szlaku, można zauważyć, że tworzą one spójny, obejmujący całą Azję system komunikacyjny. 
Stanowi to główne założenie inicjatywy One Belt One Road. Tak stworzona jednolita sieć nie tylko ułatwi bowiem handel $\mathrm{z}$ obecnymi partnerami zagranicznymi, ale również stworzy nowe możliwości podejmowania inwestycji na terenach dotychczas słabo lub niepenetrowanych, umożliwiając inwestorom bezpieczny przewóz towarów. Przewiduje się ponadto, że realizacja inicjatywy OBOR przyczyni się nie tylko do modernizacji dróg dla kolei dużych prędkości, portów lądowych i morskich oraz lotnisk, ale także do znacznego postępu w rozwoju infrastruktury przesyłowej, obejmującej gazociągi i ropociągi oraz infrastrukturę telekomunikacyjną. Powstałe udogodnienia pozwolą zaś na stworzenie różnorodnych, niewykluczających się, a wręcz uzupełniających się wariantów tras, łączących Chiny z krajami europejskimi oraz ułatwiającymi Państwu Środka podjęcie dialogu z zagranicznymi partnerami (Jedwabny..., 2017).

Należy przy tym podkreślić, że inicjatywa One Belt One Road jest ukierunkowana nie tylko na utworzenie połączeń transportowych i handlowych o charakterze fizycznym, ale również, a nawet przede wszystkim, na stworzenie i rozwijanie więzi między uczestnikami omawianego projektu. Pozwoli on bowiem na współpracę ekonomiczną, polityczną i społeczno-kulturową między Chinami a krajami objętymi trasą Nowego Jedwabnego Szlaku, przyczyniając się do stworzenia największej na świecie platformy międzynarodowej współpracy (Jinchen, 2016). Główne założenia inicjatywy One Belt One Road koncentrują się na:

- wzroście aktywności inwestycyjnej Chin oraz krajów zaangażowanych w projekt, a także wymiany handlowej między tymi krajami,

- pobudzeniu podejmowanych inwestycji infrastrukturalnych,

- osiągnięciu wyższej efektywności transportu lądowego, czyli wyższej jakości przewozów przy niższych kosztach i jednoczesnej redukcji czasu.

Dla realizacji założeń i inicjatyw Jedwabnego Szlaku został utworzony w 2014 roku specjalny fundusz o wartości 40 mld USD, a ponadto przeznaczono 10 mld USD na Nowy Bank Rozwoju krajów BRICS.

W 2016 roku rząd Chin zapowiedział rozwijanie działalności Azjatyckiego Banku Inwestycji Infrastrukturalnych (AIIB), który będzie odpowiedzialny za realizację inicjatywy One Belt One Road. Kapitał banku wynosi 100 mld USD, a jego głównym udziałowcem są Chiny (30\%). Deklaracje wspierania inicjatyw Banku, z różnymi udziałami złożyły niemalże wszystkie najbogatsze państwa świata, poza Stanami Zjednoczonymi, Japonią oraz Kanadą. Polska jako współzałożyciel banku dysponuje w nim $0,85 \%$ udziałem oraz wkładem na poziomie 830 mln USD (Gazeta Wyborcza, 2015). Do głównych zadań banku należy wspieranie sąsiadujących z ChRL biedniejszych krajów azjatyckich, takich jak Wietnam, Kambodża, Bangladesz, Birma czy też Laos, celem rozbudowy infrastruktury przemysłowej w tych państwach. Ponadto AIIB ma za zadanie rozwi- 
janie infrastruktury, ułatwiającej handel i transport towarów w ramach Nowego Jedwabnego Szlaku. Wśród głównych beneficjentów tych inwestycji wymienia się Rosję, Mongolię, Kazachstan, jak również Kraje Bliskiego Wschodu i Państwa Bałkańskie, czyli kraje o strategicznym dla Chin położeniu i słabo rozwiniętej infrastrukturze samochodowej oraz kolejowej (Go China, 2017).

Wdrażanie projektu poprzedzono gruntowną analizą stosunków poszczególnych krajów objętych trasą Nowego Jedwabnego Szlaku z ChRL. Relacje te oceniono z uwzględnieniem zarówno aspektu gospodarczego, politycznego, jak i historycznego. Chiński rząd planuje bowiem nawiązanie z każdym z tych krajów (65 krajów wzdłuż OBOR) umów strategicznych o wolnym handlu. Do tej pory podpisano porozumienia m.in. z Hong Kongiem, Singapurem, Tajwanem, Pakistanem, Szwajcarią, Islandią, Peru, Chile oraz Kostaryką. Umowy z takimi krajami, jak m.in. Japonia, Korea, Australia, Sri Lanka, Norwegia oraz kraje zrzeszone w ramach Regionalnego Kompleksowego Partnerstwa Gospodarczego, jak również Stowarzyszenia Narodów Azji Południowo-Wschodniej oraz Stowarzyszenia Narodów Azji Południowo-Wschodniej i Rady Współpracy Zatoki Perskiej są w trakcie negocjacji.

Obecnie szacuje się, że inicjatywa One Belt One Road obejmie swym zasięgiem aż 4,4 mld osób, z ponad 60 krajów, co stanowi jedną trzecią całkowitej światowej gospodarki i ponad połowę światowej ludności. Przewiduje się, że realizacja tej strategicznej inicjatywy pozwoli na „wygenerowanie 55\% światowego PNB oraz 75\% rezerw zasobów energetycznych" (Shaohua, 2015). One Belt One Road jest zatem postrzegany jako projekt o największym znaczeniu i dalekosiężnym potencjale rozwojowym, a jego wdrożenie będzie wpływało na krajową oraz zagraniczną politykę Chin, jak również na gospodarkę i stosunki międzynarodowe (South China Morning Post, 2015; Mittelstaedt, 2016). „Znaczna część chińskiego sposobu myślenia w związku z tym projektem jest oparta na geopolityce oraz ogromnych infrastrukturalnych zdolnościach eksportowych" (Godement, Kratz, 2015).

Sukces inicjatywy Nowego Jedwabnego Szlaku leży w interesie krajów znajdujących się wzdłuż wyznaczonych tras. Kluczowe znaczenie w rozwoju inicjatywy One Belt One Road mają zaś regiony Europy, zwłaszcza Europy Środkowej oraz Wschodniej, gdyż realizacja tego projektu przyczyni się do znacznego rozwoju infrastruktury tych krajów, a co za tym idzie - ich wzrostu gospodarczego. Chiński rząd zadeklarował gotowość do wyjścia naprzeciw potrzebom państw Europy Środkowo-Wschodniej proponując w 2012 roku podjęcie współpracy w ramach porozumienia „16 + 1” (Jakóbowski, 2015). Był to jeden z impulsów, które skłoniły do rozwijania sieci bezpośrednich połączeń między Chinami a Europą.

Przewiduje się, że rozwój zwłaszcza połączeń kolejowych pozwoli na istotny wzrost prędkości przepływu towarów i pieniędzy między krajami inicja- 
tywy One Belt One Road, co wpłynie na wzrost przemysłu, pobudzenie wymiany handlowej, jak również rozwój urbanizacji i wzrost populacji.

\section{Wyzwania wynikające z chińskiej ekspansji na rynku europejskim}

Wzmożona aktywność inwestycyjna firm chińskich na rynkach krajów objętych projektem Pasa i Szlaku pociąga za sobą także liczne problemy i wyzwania dla państw przyjmujących napływający kapitał. Zdaniem ekspertów obawy państw europejskich są przede wszystkim związane $\mathrm{z}$ odmiennym podejściem firm chińskich do alokacji zasobów oraz zarządzania ryzykiem inwestycji. W Chinach bowiem są one zależne od stosowanego modelu kapitalizmu państwowego, nie zaś od zasad mechanizmu rynkowego. Skutkuje to z kolei zakłócaniem obowiązujących w Europie reguł konkurencji wolnorynkowej. Decyzje chińskich inwestorów są przez to mniej przewidywalne i rodzą obawy, co do ich wpływu na przebieg dokonywanych inwestycji (Owen, 2012).

Należy wskazać na społeczną niechęć tych krajów objętych inicjatywą Pasa i Szlaku potęgowaną dodatkowo przez stosowanie tzw. dumpingu, tj. sprzedawanie chińskich towarów na rynkach zagranicznych po cenach niższych niż ceny, po których towary te są sprzedawane na rynku krajowym, lub po cenach niższych od kosztów ich wytworzenia. W ten sposób firmy chińskie przyczyniają się do tworzenia nieuczciwej konkurencji na rynkach zagranicznych, a tym samym osłabiają pozycję firm oferujących te same dobra na tych rynkach. W skrajnym przypadku może to doprowadzić do kryzysu w europejskich sektorach, w łagodnym zaś wymiarze może wywołać lokalne protesty i przyczynić się do intensyfikacji działalności lobbingowej przedsiębiorstw europejskich.

Dodatkowy czynniki zakłócający konkurencję w przyszłości jest związany $\mathrm{z}$ obecnością w Europie chińskich konglomeratów państwowych, które przez swą dominację mogą zagrażać oligopolizacją rynku europejskiego. $Z$ tego względu wszystkie chińskie firmy państwowe, czyli znajdujące się pod kontrolą Państwowej Komisji Nadzoru Aktywów i Administracji (SASAC) są postrzegane przez władze Unii Europejskiej jako jeden podmiot gospodarczy, a w ocenach jego funkcjonowania brany jest pod uwagę jego całkowity udział w rynku (European Comminssion, 2011).

Zdaniem ekspertów mimo dużej otwartości państw europejskich na napływ inwestycji zagranicznych w ramach inicjatywy One Belt One Road starają się one podchodzić z rozwagą do działań firm chińskich, zwłaszcza, gdy wiążą się z kluczowymi sektorami krajowej gospodarki kraju goszczącego. Istnieje bowiem obawa, że w ramach realizacji przyjętego modelu rozwoju gospodarki Państwa Środka, chińscy inwestorzy zlikwidują przejęte firmy europejskie i dokonają transferu aktywów o znaczeniu strategicznym z Europy do Chin. Poddając analizie dotychczasowe porozumienia nawiązane przez firmy chińskie nie tylko na rynku europejskim, ale i na całym świecie widać jednak, że inwe- 
storzy skłaniają się bardziej ku podnoszeniu wielkości produkcji oraz zwiększaniu zatrudnienia $\mathrm{w}$ przejmowanych firmach, starając się korzystać z ich doświadczenia, technologii oraz prestiżu, aniżeli koncentrują się na likwidacji przejętych przedsiębiorstw. W ten bowiem sposób firmy chińskie są w stanie uzyskać efekty synergii z rozwijania współpracy z europejskimi partnerami w ramach Nowego Jedwabnego Szlaku. Rynek europejski stwarza im bowiem warunki dla rozwijania tych obszarów prowadzonej działalności biznesowej, w których wykazują one ewidentne braki, czyli przede wszystkim w obszarze nowoczesnych technologii i pozyskiwania wysoko wykwalifikowanej kadry.

Daje to nadzieję na to, że intensyfikacja zagranicznej ekspansji Chin i zaangażowania chińskich inwestorów na arenie międzynarodowej w ramach inicjatywy One Belt One Road będzie się przyczyniała się do korzystnych zmian także w zakresie uregulowań ułatwiających podejmowanie inwestycji przedsiębiorstw zagranicznych na rynku chińskim.

Aby jednak uniknąć zagrożenia dotyczącego obiektów o znaczeniu strategicznym, kraje europejskie zaczynają stosować politykę protekcjonizmu gospodarczego (Hanemann, 2012). Nie ulega wątpliwości, że zagrożenie dla partnerów europejskich będzie wzrastało w miarę niwelowania największych słabości w chińskiej działalności biznesowej. Jednak zanim do tego dojdzie, inwestowanie w rozwój przejmowanych firm na rynku europejskim leży w najlepszym interesie Państwa Środka.

Jak wynika z opinii ekspertów, analizując wzmożoną ekspansję inwestycyjną firm chińskich w krajach objętych Jedwabnym Szlakiem, szczególnym wyzwaniem są różnice kulturowe, gdyż chińskim menedżerom często brakuje odpowiedniego doświadczenia i przygotowania do nawiązywania porozumień biznesowych z partnerami z innych kręgów kulturowych (Gao, 2012, s. 18-19). Brak takiego przygotowania, począwszy od odpowiedniej znajomości języka angielskiego, a skończywszy na rzetelnym przygotowaniu szczegółów dotyczących samej transakcji, uniemożliwia bowiem budowanie trwałych relacji oraz rozwijanie działalności inwestycyjnej firm (Luo, Tung, 2007, s. 481-498). Bardzo często wynika to $\mathrm{z}$ bagatelizowania znaczenia różnic kulturowych między firmami i ich wpływu na pomyślność porozumień biznesowych. Mimo coraz większej otwartości firm chińskich na współpracę z zagranicznymi partnerami to jednak różnice kulturowe i odmienności w sposobie myślenia bardzo często prowadzą do innych oczekiwań i napięć, co w konsekwencji może zaburzyć powodzenie przedsięwzięcia Pasa i Szlaku. Częste są przypadki nieumiejętnego zarządzania lokalnymi pracownikami przez chińskich przedsiębiorców, jak również brak dostatecznej znajomości lokalnych uwarunkowań prowadzenia biznesu w danym kraju. Ponadto mała elastyczność oraz trudność w dostosowywaniu się i przyjmowaniu międzynarodowych standardów stanowi wciąż duży problem dla chińskich inwestorów. 
Według ekspertów dużym wyzwaniem okazuje się być również praktyczne stosowanie przepisów obowiązujących w krajach Unii Europejskiej oraz innych regionach objętych inicjatywą One Belt One Road, a dotyczących m.in. wartości intelektualnej, ochrony środowiska czy też praw pracowniczych. Wyraźne różnice, zarówno w obszarze kultury korporacyjnej przedsiębiorstw, jak i w sposobie prowadzenia przez nie działalności biznesowej mogą zatem stanowić źródło dużych napięć między kadrą zarządzającą pochodzącą z firm chińskich a pracownikami firm tych krajów, a także klientami, dostawcami, instytucjami finansowymi, organami władzy i innymi podmiotami otoczenia zewnętrznego firm (Shambaug, 2012, s. 7-10).

Oprócz wyzwań, jakie stoją przed państwami przyjmującymi chiński kapitał, eksperci podkreślają również wyzwania, przed jakimi stoją same Chiny w drodze podejmowanej ekspansji i realizacji tak ambitnego projektu jak One Belt One Road. Podkreślane jest szczególnie duże ryzyko, jakie wiąże się $\mathrm{z}$ zaangażowaniem $\mathrm{w}$ kosztochłonne inwestycje o niskiej stopie zwrotu oraz zagrożenie wystąpieniem reperkusji dyplomatycznych na skutek inwestowania na obszarach niepewnych, a nawet postrzeganych jako potencjalnie wrogie.

Oceniając ekonomiczne konsekwencje i motywacje inicjatywy One Belt One Road, eksperci zwracają uwagę na obawy chińskich przedstawicieli akademickich i pisarzy, wobec nieracjonalnego lokowania przez Chiny swoich ograniczonych zasobów w czasie, gdy ich gospodarka zwalnia. Pomyślna realizacja inicjatywy One Belt One Road jest więc postrzegana jako szansa na wzmocnienie słabnącej siły chińskiego eksportu (Godement, Kratz, 2015).

\section{Podsumowanie}

Inicjatywa One Belt One Road daje wyraz aspiracjom chińskiego rządu do uczynienia z Chin „mocarstwa nowego typu”, czyli niedążącego do konfrontacji, a jednocześnie bez aspiracji hegemonistycznych.

Wzmożona aktywność chińskich przedsiębiorstw na rynkach krajów europejskich i całego świata w ramach realizacji inicjatywy One Belt One Road przyczyni się do wzrostu skali nawiązywanych bezpośrednich inwestycji zagranicznych na tych rynkach i związanym z tym napływem nowego kapitału. Tworząc powiązania z globalnymi łańcuchami wartości i rynkami eksportowymi, przewiduje się, że One Belt One Road będzie się przyczyniała do wzrostu wydatków na działalność badawczo-rozwojową, tworzenia klastrów rozwojowych oraz podnoszenia kwalifikacji pracowników. Ponadto skala i tempo wzrostu oraz komplementarność chińskiej gospodarki stwarzają wyjątkowe szanse rozwoju dla gospodarek Nowego Jedwabnego Szlaku. Należy jednak pamiętać, że charakter gospodarczego i politycznego systemu Chin może wzbudzać pewne obawy i stanowić wyzwania dla rynków krajów partnerskich, w tym dla rynku europejskiego. Jako rynek wschodzący o wciąż jeszcze nie w pełni stabilnym 
systemie finansowym Chiny mogą narazić kraje, w których inwestują na zmienność i niestabilność przepływów kapitałowych. Ponadto istnieje ryzyko dyfuzji złych praktyk do krajów One Belt One Road, w których lokalizowane są chińskie inwestycje.

Powodzenie współpracy między państwami w ramach inicjatywy One Belt One Road wymaga koordynacji stosowanych przez te kraje strategii, przy jednoczesnym poszukiwaniu perspektyw rozwojowych na poziomie globalnym.

\section{Bibliografia}

European Commission (2011). China National Bluestar/Elkem: Case No. COMP/M.6082, Brussels. March 31st 2011. Pobrano z: http://ec.europa.eu/competition/elojade/isef/case_de tails.cfm?proc_code=2_M_6082 (14.06.2015).

Gao, X. (2012). Barriers and pitfalls on foreign paths. EastAsiaForum Quaterly, 4 (2), 18-19.

Gazeta Wyborcza (28.08.2015). Polska wniesie do projektu AIIB ponad $830 \mathrm{mln}$ USD. Pobrano z: http://wyborcza.biz/Gieldy/1,132329,18642229,polska-wniesie-do-projektu-aiib-ponad830-mln-usd.html.

Go China (2017). Chiny powoluja do życia Asian Infrastructure And Investment Bank (AIIB). WPHI Szanghaj. Pobrano z: http://www.gochina.gov.pl/20150416/Chiny_powoluja_do_ zycia_Asian_Infrastructure_and_Investment_Bank.

Godement, F., Kratz, A. (2015). „One Belt, One Road”: China's Great Leap Outward. China Analysis. European Council on Foreign Relations. Pobrano z: www.ecfr.eu/public cations/summary/one_belt_one_road_chinas_great_leap_outward3055.

Guthrie, D. (2009). China and globalization. The social, economic and political transformation of Chinese society. New York/London: Routledge/Taylor and Francis Group.

Hanemann, T. (2012). How Europe should respond to growing Chinese investment. Pobrano z: http://rhg.com/articles/how-europe-should-respond-to-growing-chinese-investment (14.03.2013).

Jakóbowski, J. (2015). Wspótpraca handlowa w ramach „16+1”: sektorowy sukces eksportu żywności do Chin. Ośrodek Studiów Wschodnich im. Marka Karpia. Pobrano z: https://www.osw.waw.pl/pl/publikacje/komentarze-osw/2015-10-29/wspolpraca-handlowaw-ramach-161-sektorowy-sukces-eksportu.

Jedwabny Szlak (15.04.2017). Pobrano z: http://jedwabnyszlak.com/.

Jinchen, T. (2016), One Belt and One Road: Connecting China and the world. Mc Kinsey \& Company. Pobrano z: www.mckinsey.com/industries/capital-projects-and-infrastructure/ our-insights/one-belt-and-one-road-connecting-china-and-the-world (3.04.2017).

Luo, Y., Tung, R. (2007), International expansion of emerging market enterprises: a springboard perspective. Journal of International Business Studies, 38, 481-498.

Mittelstaedt, J.C. (2016). The implications of the Chinese OBOR One Belt One Road concept for the EU. We Build Europe. EU. Pobrano z: http://webuildeurope.eu/think-europe/the-impli cations-of-the-chinese-obor-one-belt-one-road-concept-for-the-eu.

Owen, G. (2012). Industrial Policy in Europe since the Second World War. What has been learnt? European Centre for International Political Economy Occasional Paper, 1. Pobrano z: www.ecipe.org/app/uploads/2014/12/OCC12012-revised.pdf.

Pinkerton (2014). China's „, Going Out”. Strategy: increasing, overseas, expansion. Pobrano z: https://www.pinkerton.com/blog/chinas-going-out-strategy-increasing-overseas-expansion/ (4.05.2015).

Shambaugh, D. (2012). Are China's multinational corporations really Multinational? East Asia Forum Quaterly, 4 (2), 7-10. 
Shaohua, Y. (2015). Why the 'One Belt One Road' Initiative Matters for the EU. The Diplomat, 9. Pobrano z: http://thediplomat.com/2015/04/why-the-one-belt-one-road-initiative-mattersfor-the-eu/.

South China Morning Post (2015). One Belt, One Road' initiative will define China's role as a world leader. Pobrano z: www.scmp.com/comment/insight-opinion/article/1753773/onebelt-one-road-initiative-will-define-chinas-role-world (14.05.2017).

The State Council The People's Republic of China (2015). Action plan on the Belt and Road Initiative. Pobrano z: www.english.gov.cn (25.09.2015).

\section{One Belt One Road as an Expression of a Global Expansion of China}

Keywords: One Belt One Road, OBOR, New Silk Road, China, global expansion, cooperation

Summary. Initiative of the Chinese government, One Belt, One Road, focused on the expansion of the network infrastructure linking China, the countries of Central Asia, the Middle East, Africa and Europe is meant to expand the cooperation of these countries in the implementation of infrastructure and finance related projects. Therefore the initiative will be of crucial importance to the development of the Chinese economy, its partner countries and regions in the world. In the paper the essence, significance and the expected impact of this strategic economic project of Chinese government, both on the European market and the world market have been presented.

Translated by Karolina Łopacińska

\section{Cytowanie}

Łopacińska K. (2017). One Belt One Road jako wyraz globalnej ekspansji Chin. Marketing i Zarzadzanie, 1 (47), 29-38. DOI: 10.18276/miz.2017.47-03. 